\title{
PHENOTYPIC CORRELATIONS AND BODY WEIGHTS PREDICTION USING MORPHOMETRIC TRAITS OF SNAILS IN CALABAR, NIGERIA \\ *Okon, $B$ and Ibom, L.A.
}

DOI:http://dx.doi.org/10.4314/ejesm.v4i3.2

Received August 20 2011 ; accepted August $28^{\text {th }} 2011$

\begin{abstract}
Data on hatchling body weights and morphometric traits (hatchling body shell length and hatchling body shell width) pertaining to two breeds of snails (A. marginata and A. achatina) from hatch to fourth $\left(4^{\text {th }}\right)$ week of age were analyzed. This was used to obtain correlation coefficient of morphometric traits and to generate prediction equations for live body weight of the animals. Strong, positive and significant correlations between hatchling body weight and body shell width ( $r=0.82)$ and between hatchling body weight and body shell length $(r=0.80)$ for $A$. marginata as well as between hatchling body weight and body shell length ( $r=0.81)$ and between hatchling body weight and body shell width $(r=0.86)$ for $A$. achatina were obtained. Low coefficients of determination $\left(R^{2}\right)$ were obtained with the range from $4.73 \%$ to $41.30 \%$ and from $2.12 \%$ to $50.20 \%$ for $A$. marginata and A. achatina respectively. Morphometric traits (Hatchling body shell length and body shell width) best predicted hatchling body weights of $A$. achatina and not of A. marginata snails. Strong, positive and significant correlations imply that selection for these morphometric traits will lead to improvement of hatchling body weights.
\end{abstract}

\section{Keywords: Correlation, Quantitative traits, Equations, Heliculture}

\section{Introduction}

Nigeria is greatly endowed with land snail and its domestication is receiving more attention because of its high meat quality and acceptance by her populace. The meat is cheaper, highly nutritive, contains high protein, iron and phosphorus, but low in sodium, fat and cholesterol (Akinnusi, 2002, Ejidike, 2002). Besides, it commands high price in the restaurants and markets than other conventional meat such as beef, chevron and pork (Okon et al., 2009b and Omole, 2010). Besides, the low capital and simple management practices involved have also drawn the attention of many farmers to snail farming. Thus, Okon et al. (2009b) recommended sustainable snail production in captivity for all year round supply of cheap snail meat.

There are two most popular breeds of snails in Nigeria namely Archachatina marginata and Achatina achatina (Okon et al., 2010c). Genetic improvement of these breeds of snails in order to increase their contributions to the much needed animal protein in Nigeria is inevitable. This could be achieved by estimate of genetic parameters, correlation among performance traits in the breeding objective and development of selection programme for effective planning. A quantitative measure of the animals' conformation is desirable as this will enable reliable genetic parameters for a given trait to be estimated and therefore allow its inclusion in breeding programmes. Okon et al. (1997) noted that estimates of interrelationships among body measurements can be applied speedily in selection and breeding.

Regression and correlation are the two most common techniques used to determine the relationships between and/or among two or more variables. Okon et al. (2010a, b) obtained highly significant positive correlations among morphometric traits for purebred and $F_{1}$ crossbred snails in the two parities studied. Hatchling body weight correlated most closely with hatchling shell length and shell "mouth" length in both parities. The authors further noted that about 83 to $84 \%$ and 87 to $99 \%$ of variations in hatchling weights were explained by changes in morphometric traits of purebred Albino and $F_{1}$ crossbred snails respectively. Thus, morphometric traits were recommended by Okon et al. (2010a, b) as good predictors of hatchling weights in 
juvenile purebred and $\mathrm{F}_{1}$ crossbred snails of $A$. marginata.

There are limited numbers of reports on the correlation among morphometric traits as well as prediction of live body weights from morphometric traits of these two most popular breeds of snails in Nigeria. This study was therefore undertaken to obtain correlation coefficients of morphometric traits and to provide prediction equations for predicting live body weights from morphometric traits of these two breeds of land snails.

\section{Materials and Methods Study area}

The research was carried out at the Botanical Garden, University of Calabar, Calabar - Nigeria. Calabar is situated within the geographical area between latitudes $4^{0} 58^{\prime}$ and $15^{0} 39^{\prime} \mathrm{N}$, and longitudes $8^{\circ} 17^{\prime}$ and $10^{\circ} 43^{\prime} \mathrm{E}$ of the equator with an annual temperature and rainfall ranges of $25^{\circ} \mathrm{C}$ $-30^{\circ} \mathrm{C}$ and $1260-1280 \mathrm{~mm}$ respectively. The Botanical garden as described in Okon et al. (2009a, b) is planted with trees like citrus, mango, almond, paw-paw, plantain and banana and crops like cassava, yam and maize. These trees and crops provided a micro-environment similar to the natural habitat of snails as well as shade that protected the hutches used for the study from direct sunlight. The trees and crops also protected the hutches from direct impact of heavy rainfall.

Forty (40) adult black-skinned snails, twenty (20) each of A. marginata and A. achatina were used to generate the juveniles (hatchlings). The weights of the parent breeder snails ranged from $65.25-75.20 \mathrm{~g}$ and 62.35 - $73.85 \mathrm{~g}$ for $A$. marginata and A. achatina respectively. The snails were selected based on active appearance and no injury on the foot and/or shell of the base population. Two hundred and forty (240) juveniles (hatchlings) at one-day old, one hundred and twenty (120) each obtained from separate mating of the two breeds were used for the study.

The description of the management of the snails and breeding (mating) pattern were as prescribed in Ibom (2009), Okon et al. (2009a, b) and Okon et al. (2010a, b). Data collected were number of clutch(es) and eggs laid by either breed as counted, egg weight $(\mathrm{g})$, egg length $(\mathrm{mm})$ and egg width $(\mathrm{mm})$. An electronic balance, Scout ${ }^{\mathrm{TM}}$ pro scale with $0.01 \mathrm{~g}$ to $1000 \mathrm{~g}$ sensitivity was used to measure weights, while Vernier Caliper was used to measure length and width. Phenotypic correlations among body measurements were determined according to methods outlined by Ibe (1998). Multiple regression function was used in predicting hatchling body weights from morphometric traits of the two breeds of snails studied.

\section{Results and Discussion}

The results of phenotypic correlations among morphometric traits of the two breeds of snails evaluated (Table 1) indicated positive and high significant phenotypic correlations $\left(r_{p}\right)$ between hatchling body weight and body shell width $(\mathrm{r}=0.82)$, between hatchling body weight and body shell length $(\mathrm{r}=0.80)$ of A. marginata. Similarly, there were positive and strong significant phenotypic correlations $\left(r_{p}\right)$ between hatchling body weight and body shell width $(\mathrm{r}=0.81)$, between hatchling body weight and body shell length $(\mathrm{r}=0.86)$ of $A$. achatina. Hatchling body weight and body shell length had the least correlation of $\mathrm{r}=0.71$ for $A$. marginata and $\mathrm{r}=0.78$ for A. achatina. The highest, positive, strong and closely correlated response $(r=0.86)$ between hatchling body weight and body shell length was recorded by A achatina. The positive, significant correlation values obtained in this study were also noted by Ibom (2009), Okon (2009b) and Okon et al. (2010a, b). The positive, significant correlations denoted that the pairs of traits have direct relationship or at least they are controlled by the same genes in the same direction, thus selection for one trait will lead to improvement of the others. Furthermore, the results obtained confirmed Okon et al. $(2010 \mathrm{a}, \mathrm{b})$ earlier views of high correlated responses of these morphometric traits for selection and cross breeding for genetic improvement as well as being better predictors of hatchling body weights in juvenile purebred Albino and $F_{1}$ crossbred snails.

However, the results obtained in this study are quite lower than the strong, positive and highly significant correlation values of $\mathrm{r}=0.96$ obtained by Okon et al. (2010a, b) between hatchling body weight and body shell length for the purebred white-skinned (Albino) and $\mathrm{F}_{1}$ crossbred snails of A. marginata. Also, Ibom (2009) reported strong, positive correlation value of $r=0.99$ between body 
weight and body shell length, between body weight and body shell width for purebred black-skinned snails (BS x BS), purebred white-skinned snails (WS x WS) and crossbred Black-skinned x Whiteskinned (BS $x$ WS) snails raised in Obubra, Nigeria. The differences in correlation values here could be as a result of variations in the breed and strains of snails used, mating pattern, age and size of snails used as well as other environmental factors. Besides, Okon et al. (2008) pointed out that medium sized and extra large sized snails $(77.38 \pm 2.08-167.23 \pm 3.50 \mathrm{~g})$ were collected at central agro-ecological zone and Obubra happens to fall under this ecological zone confirming the effect of age and size on morphometric traits.

The prediction equations evolved for body weights of hatchlings using the morphometric traits of A. marginata and A. achatina (Tables 2 and 3, respectively) indicated that hatchling body shell length and body shell width best predicted body weight of $A$. achatina juvenile snails as there were little or no differences between the actual and predicted live weights of snail hatchlings using multiple regression equations (Table 4). Unexpectedly, for A. marginata snail, hatchling body shell length and body shell width did not closely predict hatchling body weights of the snail. This may be due to the effect of breed as blackskinned A. marginata is naturally superior and bigger in size than the black-skinned A. achatina, as well as the method of statistical analysis adopted. Okon et al. (2010a, b) noted that using any one of the morphometric traits studied in a simple regression is a better predictor of hatchling body weight (juvenile snails) in purebred or crossbred of $A$. marginata and A. achatina, whereas Olawoyin and Ogogo (2006) had reported shell length as a better predictor of body weight for growing snails.

The low percent of coefficients of determination $\left(\mathrm{R}^{2} \%\right)$ of $(4.70-41.30 \%)$ and $(2.12$ - $50.20 \%$ ) obtained in this study for both $A$. marginata and $A$. achatina, respectively indicate that variations in body weights of these breeds of juvenile snails cannot be explained only by changes in body shell length and body shell width. This could be due to methods of statistical analysis used as earlier noted. Okon et al. (2010a, b) used simple correlation analysis for a single trait and obtained very high coefficient of determination
$\left(\mathrm{R}^{2}\right)$, whereas in this study, multiple correlation analysis involving two traits (body shell length and body shell width) was used in the equations and the $\mathrm{R}^{2}$ values obtained are low.

\section{Conclusion}

The results of the study revealed high, positive significant correlation values between body weight and morphometric traits (body shell length and body shell width) in both $A$. marginata and $A$. achatina juvenile snails. Thus body weight and these morphometric traits may be chosen to characterize juvenile snails of both breeds. For prediction of body weights using multiple regression equations, body shell length and body shell width are better predictors of hatchling body weights of A. achatina than for A. marginata juvenile snails.

\section{References}

Akinnusi, O. (2002). Introduction to snails and snail farming. Abeokuta, Nigeria. Triolas Exquisite Ventures.

Ejidike, B. N. (2002). Snail Rearing Practices in Southern Nigeria. Proceeding of $27^{\text {th }}$ Annual Conference of Nigerian Society for Animal Production (NSAP), March 17-21 ${ }^{\text {st }}, 2002$. Akure, Nigeria, Pp. 307 - 308.

Ibe, S. N. (1998). An Introduction to Genetics and Animal Breeding. Ikeja, Nigeria, Longman Nigeria Plc.

Ibom, L. A. (2009). Variations in reproductive and growth performance traits of white-skinned $\mathrm{x}$ black-skinned African giant snail hatchlings [Archachatina marginata (Swainson)] in Obubra, Nigeria. Doctor of Philosophy Dissertation, Department of Animal science, University of Calabar, Calabar, Nigeria. (Unpublished).

Okon, B., Ogar, I. B. and Mgbere, O. O. (1997). Interrelationship of live body measurements of broiler chicken in a humid tropical environment. Nigeria Journal of Animal Production Vol. 24 No. $1 \& 2$, Pp. $7-12$.

Okon, B., Ibom, L. A., Etuk, N. E. and Akpan, E. W. (2008). Variations in growth patterns and conformation of snail: Influence of strain and location on isometry of growth in Cross River State Nigeria. Journal of Agriculture, Forestry and the Social Sciences (JOAFSS). Vol. 6 No. 2, Pp. $218-226$. 
Okon, B., Ibom, L. A., Ekpo, I. A. and Ewa, E. C. (2009a). Evaluation of Reproductive performance and some egg quality parameters of Albino snails (Archachatina marginata saturalis (Swaison). Journal of Applied Sciences, Vol. 12 No. 1, Pp. $8234-8240$.

Okon, B., Ibom, L. A., Williams, M. E. and Akpakpan, I. E. (2009b). Comparative Evaluation of Reproductive performance and some egg quality parameters of Black and White Skinned Snails. Global Journal of Agricultural Sciences Vol. 8, No. 1 Pp. $77-80$.

Okon, B., Ibom, L. A., Williams, M. E. and Akwa, N. T. (2010a). Parity Effects on Breeding and morphometric traits of Eggs and Hatchlings of purebred Albino snails (Archachatina margina (Swainson). Journal of Agriculture, Biotechnology and Ecology, Vol. 3, No. 1. Pp. $44-54$.

Okon, B., Ibom, L. A., Williams, M. E. and Etukudo, D. M. (2010b). Effects of Parity on
Breeding and Morphometric traits of eggs and hatchlings of $F_{1}$ crossbred of snails (Archachatina marginata var. saturalis). Journal of Agriculture, Biotechnology and Ecology, Vol. 3. No. 1. 36-43. Okon, B., Ibom, L. A., Williams, M. E. and Ekong, N. B. (2010c). Effects of Breed on Reproductive Efficiency of two most popular snails (Archachatina marginata (S) and Achatina achatina $(L)$ in Nigeria. Livestock Research for Rural Development Vol. 22 No. 1 (In Press).

Olawoyin, O. O. and Ogogo, A. U. (2006). Prediction of optimum Stocking Density in Growing African Giant land snails. Tropical Journal of Animal Science, Vol. 9, No. 2, Pp. 72 84.

Omole, A. J. (2010). Performance and carcass Analysis of growing snails fed Calopogonium mucunoidis (Calopo) and Pueraria phasioloides (Kudzupuero). Nigerian Journal of Animal Production Vol. 37 (1\&2), Pp. 85 - 90.

Table 1 Phenotypic Correlation (rp) among Morphometric Traits of Snails.

\begin{tabular}{cccc}
\hline & \multicolumn{3}{c}{ A. marginata } \\
& wt & $\mathrm{w}$ & $\mathrm{L}$ \\
\hline $\mathrm{wt}$ & & 0.82 & 0.80 \\
$\mathrm{~W}$ & 0.81 & & 0.71 \\
$\mathrm{~L}$ & 0.86 & 0.78 & \\
\hline \multicolumn{3}{c}{ A. achatina } \\
\hline
\end{tabular}

$\mathrm{wt}=$ body weight, $\mathrm{w}=$ hatchling body shell width, $\mathrm{L}=$ hatchling body shell length .

Table 2 Prediction Equations for Body Weights of A. marginata Snail.

\begin{tabular}{ccccc}
\hline $\begin{array}{c}\text { Age } \\
(\text { Weeks })\end{array}$ & Equations & $\mathrm{R}$ & $\mathrm{R}^{2}$ & \\
\cline { 1 - 4 } 0 & $\mathrm{Y}=-0.436-0.0564 * \mathrm{~L}+0.191 * \mathrm{~W}$ & 0.643 & 0.413 & 0.121 \\
1 & $\mathrm{Y}=1.632-0.0527 * \mathrm{~L}+0.0207 * \mathrm{~W}$ & 0.427 & 0.182 & 0.109 \\
2 & $\mathrm{Y}=1.95+0.00238 * \mathrm{~L}-0.0602 * \mathrm{~W}$ & 0.321 & 0.103 & 0.110 \\
3 & $\mathrm{Y}=2.144+0.00716 * \mathrm{~L}-0.0715 * \mathrm{~W}$ & 0.366 & 0.134 & 0.101 \\
4 & $\mathrm{Y}=1.885-0.00353 * \mathrm{~L}-0.0326 * \mathrm{~W}$ & 0.217 & 0.047 & 0.095 \\
\hline
\end{tabular}

$\mathrm{L}=$ hatchling body shell length; $\mathrm{W}=$ hatchling body shell width,

$*=$ multiplication sign; $\mathrm{SEE}=$ Standard Error of Estimate. 
Table 3 Prediction Equations for Body Weights of A. achatina snail.

\begin{tabular}{cccccc}
\hline $\begin{array}{c}\text { Age } \\
(\text { Weeks })\end{array}$ & Equations & $\mathrm{R}$ & $\mathrm{R}^{2}$ & SEE \\
\hline 0 & $\mathrm{Y}=0.652-0.00837 * \mathrm{~L}-0.000969 * \mathrm{~W}$ & 0.146 & 0.0212 & 0.024 \\
1 & $\mathrm{Y}=0.857-0.313 * \mathrm{~L}+0.0138 * \mathrm{~W}$ & 0.653 & 0.426 & 0.017 \\
2 & $\mathrm{Y}=1.166-0.0407 * \mathrm{~L}+0.519 * \mathrm{~W}$ & 0.569 & 0.323 & 0.031 \\
3 & $\mathrm{Y}=1.342-0.0488 * \mathrm{~L}+0.0104 * \mathrm{~W}$ & 0.472 & 0.223 & 0.052 \\
4 & $\mathrm{Y}=1.897-0.0747 * \mathrm{~L}+0.00143 * \mathrm{~W}$ & 0.709 & 0.502 & 0.046 \\
\hline
\end{tabular}

$\mathrm{L}=$ hatchling body shell length; $\mathrm{W}=$ hatchling body shell width,

$*=$ multiplication sign; SEE $=$ Standard Error of Estimate

Table 4 Comparison between Actual and predicted Liveweight (g) of Snail Hatchlings using Regression Equations.

\begin{tabular}{lcccc}
\hline \multirow{2}{*}{ Age (Weeks) } & \multicolumn{2}{c}{ A. marginata } & \multicolumn{2}{c}{ A. achatina } \\
\cline { 2 - 5 } & Actual & Predicted & Actual & Predicted \\
\hline 0 (At Hatchling) & 1.140 & 1.017 & 0.543 & $0.540^{*}$ \\
1 & 1.210 & 1.120 & 0.597 & $0.598^{*}$ \\
2 & 1.297 & 1.198 & 0.670 & $0.684^{*}$ \\
3 & 1.377 & 1.283 & 0.783 & $0.788^{*}$ \\
4 & 1.457 & 1.363 & 0.857 & $0.856^{*}$ \\
\hline
\end{tabular}

*values with asterisk best predict actual live weight. 